\title{
Pengaruh perbedaan jumlah penambahan binder uretan dan berbagai motif embossing terhadap kualitas kulit reject
}

\section{The influence of differences in addition amount of urethane binder and various embossing motives to the quality of rejected leather}

\author{
Emiliana Kasmudjiastuti*, Prayitno, Bidhari Pidhatika, Gresy Griyanitasari \\ Balai Besar Kulit, Karet dan Plastik, Jl. Sokonandi No. 9 Yogyakarta 55166, Indonesia \\ *Penulis korespondensi. Telp: + 62274 512929, 563939, Fax: + 62274563655 \\ E-mail: emil_bbkkp@yahoo.com
}

Diterima: 7 April 2016 Direvisi: 4 Mei 2016 Disetujui: 20 Mei 2016

\begin{abstract}
Rejected tanned leather is tanned lether product with damages of more than $30 \%$ of its total surface area, but can be improved by embossing. Embossing is the provision of patterns that influences the properties of articles and contributes to the closure of the defects on the surface of leather. This study aims to determine the influence of urethane binder and embossing motives to the quality of rejected leather for shoe upper applications. Variables investigated were urethane binder composition (100, 150, and 200 part in 1000 part of base coat) and embossing motives (crocodile, ostrich, shark fish, and milled motive). The quality of the leather was then tested in terms of organoleptic properties (feel, flexibility, visual appearance), mechanical properties (tear strength, tensile strength, elongation at break, rub fastness (dry, wet), adhesive strength of cover paint (dry, wet), and flexing resistance), physical properties (WVP and WVA), as well as morphology (SEM). The results showed that the addition of urethane binder and embossing patterns affect the quality of shoe upper leather, i.e. in general covering the leather defects and increasing the visual appearance (organoleptic properties), and changing the collagen network structure (based on SEM test). Visually preferred skin is skin with the addition of 200 parts of the urethane binder and crocodile patterned leather.
\end{abstract}

Keywords: Urethane binder, embossing, rejected leather, WVP, leather morphology.

\begin{abstract}
ABSTRAK
Kulit tersamak reject adalah produk dengan jumlah luasan kerusakan lebih besar dari 30\%, namun dapat diperbaiki dengan embossing. Embossing adalah metode pemberian motif yang dapat mempengaruhi sifat artikel dan dapat memberikan kontribusi terhadap penutupan cacat-cacat pada permukaan kulit. Penelitian ini bertujuan untuk mengetahui pengaruh penambahan binder uretan dan motif embossing pada kulit reject terhadap kualitas kulit bagian atas sepatu. Variabel penelitian terdiri atas jumlah binder uretan (100, 150, dan 200 gram dalam 1000 gram campuran lapisan dasar) dan motif embossing (kulit buaya, burung unta, ikan hiu, dan milled). Pengujian mutu kulit terdiri atas pengujian organoleptis (pegangan, kelemasan, kenampakan), mekanik (ketahanan sobek, kekuatan tarik, kemuluran, ketahanan gosok cat (kering dan basah), kekuatan rekat cat tutup kering dan basah, ketahanan bengkuk), fisis (water vapor permeability (WVP), water vapor absorption (WVA)), dan morfologi (scanning electron microscopy (SEM)). Hasil penelitian menunjukkan bahwa penambahan binder uretan dan motif embossing berpengaruh terhadap mutu kulit bagian atas sepatu, yaitu secara umum dapat menutup cacat-cacat dan menambah keindahan visual dan mengubah struktur jaringan kolagen (hasil uji SEM). Secara visual kulit yang disukai adalah kulit dengan penambahan binder uretan sebesar 200 bagian dan bermotif kulit buaya.
\end{abstract}

Kata kunci: Binder uretan, embossing, kulit reject, $W V P$, morfologi kulit. 


\section{PENDAHULUAN}

Kerusakan kulit sapi dapat terjadi pada saat hewan masih hidup (ante-mortem), saat pengulitan (post mortem), dan saat pengawetan (ISO, 1998). Menurut Standar Nasional Indonesia (SNI), kualitas kulit sapi mentah dan pikel dapat digolongkan dalam kualitas I-V dan reject (R) atau afkir. Kulit kualitas reject adalah kulit dengan jumlah luas kerusakan $>30 \%$ (BSN, 1994). Selain itu, kulit wet blue dan wet white sangat sensitif terhadap serangan jamur karena kandungan air dan asam yang masih tinggi, sehingga kerusakannya akan mempengaruhi kualitas akhir dan menurunkan harga jual kulit (Fountura \& Gutterres, 2015).

Kulit yang rusak dapat diatasi dengan ditutup atau diperbaiki (corrected) atau diampelas, kemudian dilanjutkan dengan proses finishing menggunakan pigmen dalam jumlah besar untuk menutupi kerusakan kulit. Namun kelemahan dari metode ini adalah kulit menjadi seperti plastik. Agar kulit tampak natural dalam pegangan maka salah satu cara yang dapat dilakukan adalah pemberian motif buatan dengan metode embossing, meskipun cacat lebih dalam tidak bisa diatasi dengan tindakan koreksi ini. Penutupan cacat kulit dimaksudkan untuk memperbaiki goresan yang terbuka, kerusakan dan luka pada permukaan kulit serta untuk meningkatkan nilai tambah (Kabeer, 2014).

Finishing kulit merupakan tahapan akhir pada proses penyamakan kulit yang akan menentukan penampilan produk jadi. Tujuan finishing antara lain untuk memberikan penampilan yang menarik. Niculescu et al. (2015) menyatakan bahwa proses finishing juga dapat menutup/menyamarkan kerusakan kulit. Untuk memberikan efek kulit bermotif, sebelumnya dilapisi dengan lapisan pigmen (pigment coat) lalu dicetak dengan motif (embossing) dengan suhu dan tekanan yang tinggi (Wang et al., 2010), kemudian diberikan lapisan atas (top coat) dan diplating (seterika). Pemberian lapisan atas dimaksudkan untuk melindungi lapisan di bawahnya (lapisan pigmen) sehingga tahan terhadap gosok kering dan basah setelah diplating. Nitroselulosa sebagai top coat dapat memberikan perlindungan pada permukaan kulit, ketahanan terhadap air, dan ketahanan gosok cat (Gumel \& Dambatta, 2013; Wakaso, 2014). Perlakuan plating ditujukan untuk menjamin perekatan dan pemerataan film, yang akan berpengaruh pada kenampakan akhir dari kulit. Penggunaan motif emboss memungkinkan peningkatan kualitas kulit dari segi penampilannya (appearance).
Lapisan pigmen dapat berfungsi sebagai lapisan dasar yang prinsipnya terdiri dari pigmen, resin/binder (akrilik, uretan, butadiena, vinil) dan bahan tambahan. Fungsi binder bila dicampur dengan pigmen adalah untuk memberikan daya rekat pada kulit, serta memberikan kelemasan dan kelenturan pada kulit. Binder akrilik mempunyai sifat fleksibel dan lunak (Hoefler et al., 2013), memiliki daya perekatan yang baik, sensitif terhadap pelarut dan kekuatan mekanik kurang baik (Jankauskaite et al., 2014). Binder uretan terdiri atas dua tipe yaitu uretan alifatik dan aromatik. Tipe alifatik banyak digunakan secara luas karena mempunyai ukuran partikel yang kecil, mempunyai daya menutup yang luar biasa, dan memiliki sifat fisika dan mekanik yang baik (Wakaso, 2014). Binder uretan sebagai perekat memiliki kualitas yang baik dalam pembuatan kulit untuk tas, sepatu, pakaian dan aksesoris, dan menghasilkan karakteristik lebih dibandingkan dengan binder akrilik (Basaran et al., 2012). Karakteristik lain dari binder uretan adalah memiliki sifat mekanik, kelemasan dan water vapour permeability (WVP) yang baik (Jankauskaite et al., 2014). Sifat-sifat tersebut merupakan sifat-sifat yang penting dalam aplikasi kulit bagian atas sepatu.

Kecocokan (compatibility) antara lapisan atas (top coat) dengan lapisan film (base coat) merupakan faktor yang sangat penting. Jika lapisan film tipis maka kekuatan kohesi akan rendah dan dapat membentuk film yang tidak rata (discontinuous) pada permukaan kulit. Temperatur yang rendah pada saat plating akan mempengaruhi flexing (ketahanan bengkuk) dan dapat mengurangi daya rekat antara lapisan film yang terbentuk dengan permukaan kulit. Bahan untuk sepatu bagian atas sebaiknya mempunyai sifat kenyamanan dan kesehatan untuk kaki selama penggunaan sepatu. Water vapour absorption (WVA) dan water vapour permeability (WVP) dari bahan yang digunakan untuk bagian atas sepatu sangat penting untuk mengevaluasi sifat-sifat tersebut (Smiechowski et al., 2014). Kemampuan bahan untuk dilalui/ ditembus uap air sangat besar pengaruhnya terhadap kenyamanan si pemakai sepatu. Permeabilitas yang rendah akan menyebabkan kaki basah. Permeabilitas tinggi juga tidak cukup, harus digabungkan dengan sifat sifat absorpsi yang tinggi, karena absorpsi dari keringat oleh bahan untuk sepatu akan membantu kaki tetap kering. Kulit mempunyai sifat permeabilitas dan absorpsi yang tinggi (Gulbiniene et al., 2007). WVP dipengaruhi oleh 
teknik operasional dalam pembuatan kulit seperti penyamakan ulang dan peminyakan, tetapi yang sangat penting adalah proses finishing termasuk didalamnya struktur kimia dari komponen bahan finishing (Tang et al., 2013; Smiechowski et al., 2014). WVP kulit yang belum difinish (kulit kras) lebih baik daripada kulit yang difinish (Tang et al., 2013). Hal ini disebabkan adanya perbedaan tekanan antara dua sisi kulit kras dan adanya gugus hidrofilik pada rantai kolagen. Untuk kulit finish WVP hanya membawa molekul air melalui kapiler kulit didorong oleh perbedaan tekanan uap air antara dua sisi kulit (Tang et al., 2013). Menurut Smiechowski et al. (2014) nilai WVP kulit finish dengan perlakuan panas dapat turun karena adanya pengurangan jumlah gugus hidrofilik dari makromolekul kolagen dan penurunan porositas kulit. Lebih lanjut dinyatakan oleh Tang et al. (2013) dan Bekele (2014) bahwa salah satu sifat penting dari kulit untuk bagian atas sepatu adalah WVP, karena WVP adalah merupakan salah satu sifat fisis kulit yang mempengaruhi breathability dan comfortable feelings. Oleh karena itu untuk membantu kulit mempunyai sifat breathability yang baik, kulit dilapisi dengan film yang tipis. Makin tebal pelapisan, WVP makin rendah (Smiechowski et al., 2014).

Penelitian ini bertujuan untuk mengetahui pengaruh penambahan binder uretan dan motif embossing terhadap sifat organoleptis dan mekanik, serta morfologi kulit reject. Penelitian serupa pernah dilakukan (Widari et al., 2007) untuk motif kulit reptil dengan pengujian kekuatan tarik, kemuluran, ketahanan gosok cat tutup, kekuatan sobek, dan ketahanan Zwick. Dalam penelitian ini dilakukan untuk pertama kalinya motif-motif selain motif reptil, dengan pengujian yang lebih lengkap, yaitu selain uji-uji tersebut di atas, disertakan uji organoleptis yang melibatkan panelis, uji WVP dan WVA, serta scanning electron microscopy (SEM).

\section{BAHAN DAN METODE Bahan Penelitian}

Bahan baku yang digunakan dalam penelitian adalah kulit sapi wet blue kualitas reject yang berasal dari penyamak kulit di Yogyakarta. Bahan penyamak ulang, bahan pewarna, minyak sulfonasi dan bahan pembantu untuk penyamakan ulang serta bahan-bahan untuk finishing seperti liquid dyes, pigmen, binder akrilik (medium hardness), binder uretan (medium softness), binder protein (medium hardness), wax-filler, penetrator, thinner, lak air dan lak solvent diperoleh dari leveransir obat-obat kulit di Yogyakarta.

\section{Peralatan Penelitian}

Alat yang digunakan dalam penelitian meliputi: drum penyamakan, alat pentang, spray gun dan mesin seterika serta emboss motif kulit buaya, burung unta, ikan hiu, dan milled, alat uji crockmeter (AATCC model M238 AA), alat uji kekuatan tarik (Zwick Roell ZO20 tipe KAPTC), alat uji ketahanan sobek, alat uji ketahanan bengkuk, alat uji kekuatan rekat cat tutup dan scanning electron microscope (Jeol JSM6360LA).

\section{Metode Penelitian \\ Proses penyamakan ulang}

Kulit wet blue dari kulit sapi diseragamkan tebalnya dengan proses shaving dengan ketebalan 1-1,2 mm. Setelah tebal disesuaikan, proses penyamakan ulang dilanjutkan sampai dengan kulit kras warna, diikuti dengan proses finishing. Formula proses penyamakan ulang disajikan pada Tabel 1.

\section{Finishing kulit}

Dalam penelitian ini variabel yang dipelajari pada proses finishing meliputi jumlah binder uretan (RU) sebanyak 100, 150, dan 200 bagian dan jenis motif (kulit buaya, ikan hiu, burung unta dan milled). Tahapan finishing meliputi pemberian lapisan dasar (base coat); proses embossing pada suhu $95^{\circ} \mathrm{C}$, tekanan 200 bar dan waktu 20 detik; pemberian lapisan atas (top coat); plating pada suhu $90^{\circ} \mathrm{C}$, tekanan 50 bar dan waktu 0,5 detik. Ada pun formula base coat dan top coat, masingmasing disajikan pada Tabel 2 dan 3. Khusus untuk kulit dengan pemberian motif ikan hiu, perlakuan embossing dilakukan dua kali perlakuan dengan arah membujur dan melintang, mengingat motif tersebut adalah motif yang digunakan di pasaran untuk bagian atas sepatu. Sebagai kontrol, kulit tanpa pemberian motif (polos) disertakan dalam penelitian ini. Kulit tersebut hanya dikenai proses plating pada suhu suhu $90^{\circ} \mathrm{C}$, tekanan 100 bar, dan waktu 1 detik, setelah pemberian base coat.

\section{Pengujian sifat organoleptis dan mekanik}

Pengujian yang dilakukan meliputi uji organoleptis dan uji mekanik. Uji organoleptis dilakukan oleh sembilan panelis dari Balai Besar Kulit, Karet, dan Plastik (BBKKP) untuk menilai performance kulit (pegangan, kelemasan 
Tabel 1. Formula penyamakan ulang (retanning).

\begin{tabular}{|c|c|c|c|c|}
\hline Proses & $\%(b / b)$ & Bahan & $\begin{array}{c}\text { Lama proses } \\
\text { (menit) }\end{array}$ & Keterangan \\
\hline \multirow[t]{3}{*}{ Rewetting } & 200 & $\operatorname{Air}\left(40^{\circ} \mathrm{c}\right)$ & & \\
\hline & 0,5 & Alcem CSAN & & \\
\hline & 0,2 & FA & 60 & Drain, wash \\
\hline \multirow[t]{7}{*}{ Retanning } & 100 & Air $\left(40^{\circ} \mathrm{c}\right)$ & & \\
\hline & 0,5 & Yolkanol L5CC & 30 & \\
\hline & 1,5 & Retingan R7 & 30 & \\
\hline & 1 & Tanigan PAK & 30 & \\
\hline & 2 & Chromosal B & & \\
\hline & 1 & Tanigan OS & 60 & \\
\hline & 1 & Sodium format & 20 & ON/ drain, wash \\
\hline Dyeing, & 50 & $\operatorname{Air}\left(40^{\circ} \mathrm{c}\right)$ & & \\
\hline \multirow{12}{*}{ Fatliquoring } & 1 & Yolkanol L5CC & 20 & \\
\hline & 2 & Novaltan PF & 30 & \\
\hline & 1,5 & Mimosa & & \\
\hline & 1 & Tanigan PR & 40 & \\
\hline & $\begin{array}{c}1,5 \\
1\end{array}$ & $\begin{array}{c}\text { Dyestuffts : } \\
\text { Baygenol brown EDN } \\
\text { Baygenol brown CBN }\end{array}$ & 40 & \\
\hline & 1,5 & Mimosa & 40 & \\
\hline & 2 & Leathernol SPU & & \\
\hline & 2 & Leathernol BML & & \\
\hline & 2 & Eurokanol 821 & 30 & \\
\hline & 100 & $\operatorname{Air}\left(60^{\circ} \mathrm{c}\right)$ & 30 & \\
\hline & 1 & FA & 20 & \\
\hline & 1 & FA & 20 & Drain, wash \\
\hline
\end{tabular}

Tabel 2. Formula base coat.

\begin{tabular}{cccc}
\hline Base coat & $\begin{array}{c}\text { Variasi } 1 \\
\text { (gram) }\end{array}$ & $\begin{array}{c}\text { Variasi } 2 \\
\text { (gram) }\end{array}$ & $\begin{array}{c}\text { Variasi 3 } \\
\text { (gram) }\end{array}$ \\
\hline Pigmen & 75 & 75 & 75 \\
Resin Akrilik (RA) & 200 & 150 & 100 \\
Resin Uretan (RU) & 100 & 150 & 200 \\
Binder protein & 50 & 50 & 50 \\
Wax Filler & 30 & 30 & 30 \\
Penetrator & 20 & 20 & 20 \\
Air & 525 & 525 & 525 \\
\hline
\end{tabular}

Keterangan: Embossing dengan variasi 4 motif, yaitu motif kulit buaya, ikan hiu, burung unta, dan milled, dengan kondisi operasi suhu $95^{\circ} \mathrm{C}$, tekanan 200 bar, dan waktu 20 detik.

dan kenampakan). Kriteria penilaian yang telah disepakati bersama: sangat baik (86-100), baik (76-85), cukup (66-75), kurang $(<65)$. Uji mekanik meliputi uji kekuatan sobek, kekuatan tarik, kemuluran, ketahanan gosok cat (basah, kering), kekuatan rekat cat tutup (basah, kering), ketahanan bengkuk, WVP, WVA, dan pengamatan morfologi kulit. Adapun dasar dari pengujian 
Tabel 3. Formula top coat.

\begin{tabular}{|c|c|}
\hline \multicolumn{2}{|c|}{ Pemberian efek } \\
\hline BI : 100 gram & BI : 100 gram \\
\hline LW : 200 gram & RU : 100 gram \\
\hline LD : 50 gram & LD : 25 gram \\
\hline Spray efek & Air : 275 gram \\
\hline & Spray 2 kali \\
\hline \multicolumn{2}{|c|}{ Pemberian top coat } \\
\hline LS : 250 gram & Plating dengan kondisi operasi: \\
\hline Slip agent : 10 gram & Suhu $90^{\circ} \mathrm{C}$ \\
\hline Thinner : 750 gram & Tekanan 50 bar \\
\hline Spray 2 kali & Waktu 0,5 detik \\
\hline
\end{tabular}

Keterangan:

BI: Binder protein; LW: Lacquer water; LD: Liquid dyes; LS: Lacquer solvent; RU: Resin uretan

mekanik tersebut adalah SNI 0234: 2009 untuk Kulit bagian atas alas kaki - kulit boks.

\section{HASIL DAN PEMBAHASAN Sifat Organoleptis}

Hasil rata-rata penilaian mutu kulit secara organoleptis (pegangan dan kelemasan) disajikan pada Gambar 1 dan 2, sedangkan hasil rata-rata untuk kenampakan serta perbandingan kenampakan dari kulit sebelum dan sesudah embossing, masing-masing disajikan pada Gambar 3 dan 4. Gambar 1, 2, dan 3, yang menampilkan nilai rata-rata serta standar deviasi, menunjukkan bahwa secara umum, sifat organoleptis kulit meningkat dengan adanya penambahan binder uretan dan pemberian motif dengan metode embossing.

Rata-rata nilai panelis untuk sifat organoleptis pegangan berada pada kategori cukup dan baik, yaitu antara nilai minimum $74 \pm 7$ (RU 150 , motif buaya) dan maksimum $83 \pm 4$ (RU 200, motif ikan hiu).

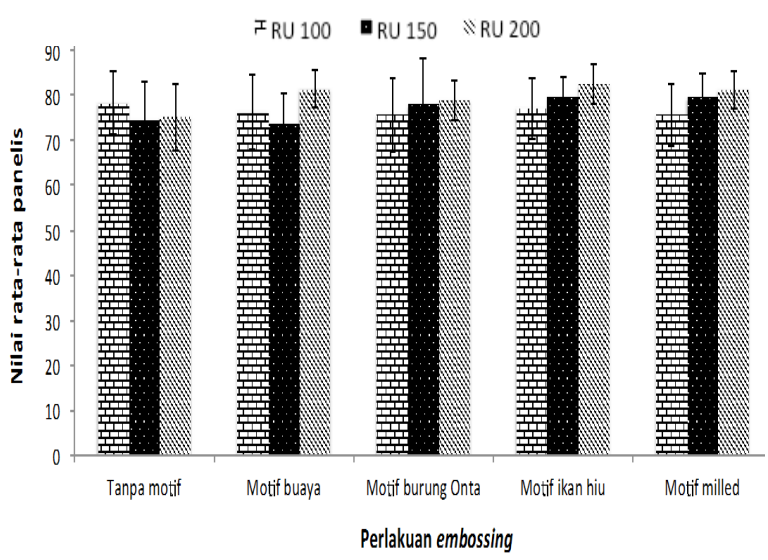

Gambar 1. Hasil penilaian panelis terhadap sifat organoleptis pegangan.
Rata-rata nilai panelis untuk sifat organeleptis kelemasan berada pada kategori cukup dan baik, yaitu antara nilai minimum $72 \pm 7$ (RU 150, tanpa motif dan motif buaya) dan maksimum $85 \pm 4$ (RU 200, motif ikan hiu).

Rata-rata nilai panelis untuk sifat organoleptis kenampakan berada pada kategori cukup dan baik, yaitu antara nilai minimum $71 \pm 9$ (RU 150, tanpa motif) dan maksimum $85 \pm 5$ (RU 200, motif buaya).

Berdasarkan data-data tersebut di atas, penambahan RU sebesar 200 bagian dalam 1000 bagian base coat, yang diikuti dengan embossing dengan motif kulit ikan hiu memberikan sifat pegangan dan kelemasan yang paling disukai oleh panelis. Hal ini sesuai dengan pernyataan Jankauskaite et al. (2014) bahwa salah satu karakteristik binder uretan adalah memiliki sifat kelemasan yang baik. Adapun dari segi kenampakan, penambahan RU 200 bagian dan motif buaya paling disukai. Pemberian nilai yang tinggi pada motif kulit buaya da-

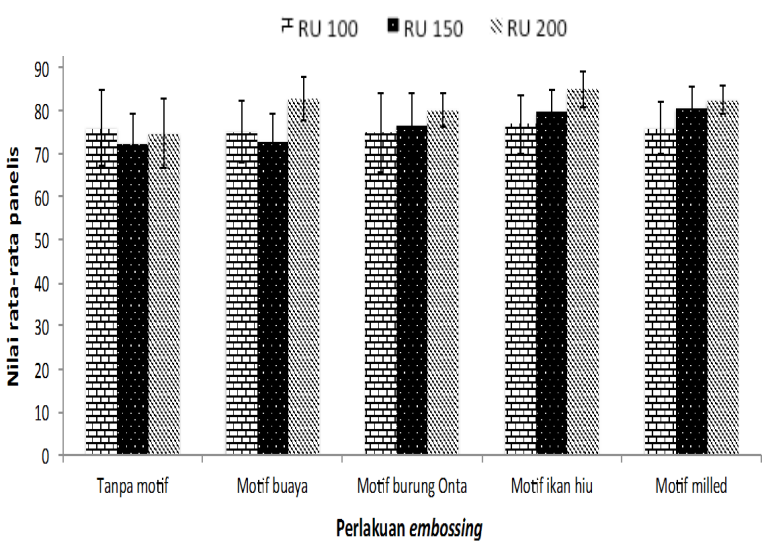

Gambar 2. Hasil penilaian panelis terhadap sifat organoleptis kelemasan. 
pat disebabkan karena kulit buaya tampak elegan dan pada umumnya berharga tinggi.

Sebaliknya, para panelis memberikan nilai rata-rata kenampakan kulit pada kulit tanpa motif lebih rendah dari pada kulit bermotif pada penggunaan binder uretan $(100,150$, dan 200 bagian), karena penggunaan pigmen (jumlah 75 bagian) belum cukup untuk menutup seluruh cacat yang ada pada permukaan kulit, sehingga tampak tidak homogen. Ketidakhomogenan ini akan tersamarkan dengan pemberian motif. Hal ini tampak pada Gambar 3 di mana nilai rata-rata kenampakan untuk kulit dengan berbagai motif relatif lebih tinggi dibandingkan dengan kulit tanpa motif. Hal ini memperkuat bukti bahwa pemberian motif dapat menambah nilai keindahan secara visual (tampak pada Gambar 4) dan tentunya nilai jual kulit reject.

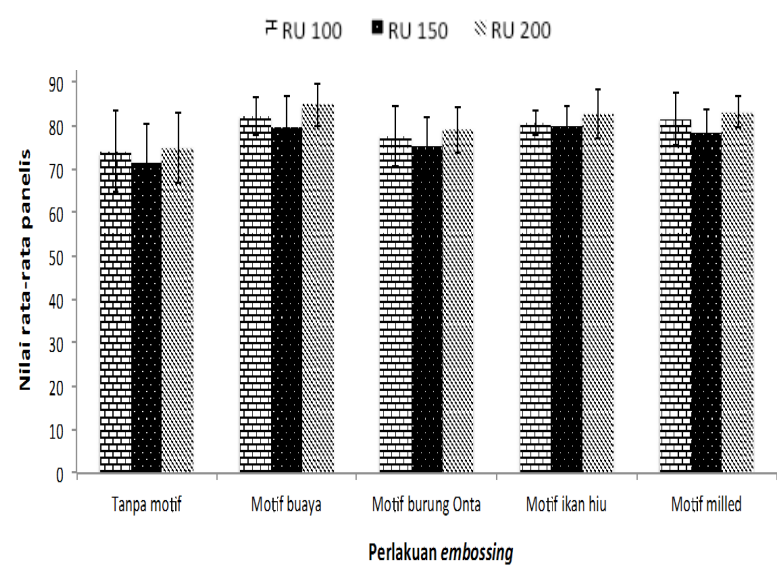

Gambar 3. Hasil penilaian panelis terhadap sifat organoleptis kenampakan.

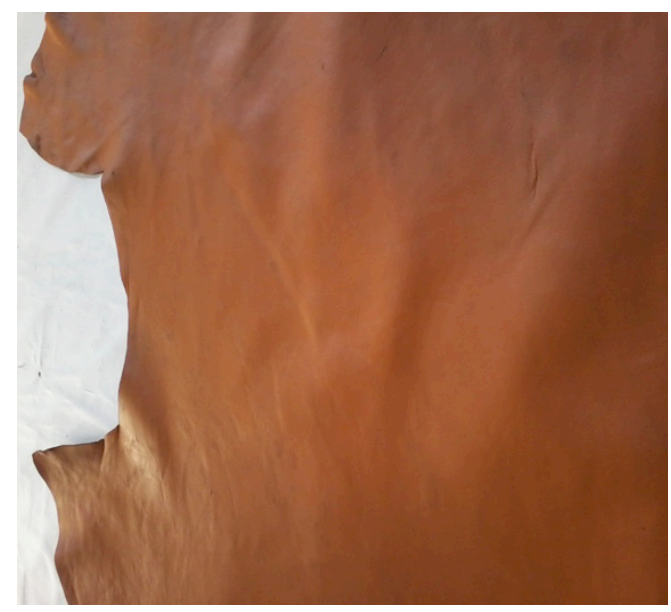

Ketahanan Sobek, Kemuluran, dan Kekuatan tarik

Ketahanan sobek, kekuatan tarik, dan kemuluran merupakan sifat-sifat kulit yang saling berhubungan dan sangat penting dalam aplikasi bahan bagian atas sepatu, yang dipengaruhi oleh tahapan proses penyamakan dan peminyakan sebelum proses finishing. Pada umumnya, derajat ikat silang serat kolagen yang tinggi akan menghasilkan kulit dengan kekuatan tarik yang tinggi, namun ketahanan sobek dan kemuluran yang rendah. Jika derajat ikat silang kolagen rendah, molekul-molekul minyak dalam proses peminyakan akan mudah masuk ke dalam sela-sela serat kolagen. Hal ini menyebabkan kekuatan tarik yang rendah, namun ketahanan sobek dan kemuluran yang tinggi karena molekul-molekul minyak berfungsi sebagai pelumas yang membuat pergeseran serat satu dengan lainnya menjadi mudah dan tidak menimbulkan kerusakan. Berdasarkan teori tersebut, ketahanan sobek, kekuatan tarik, dan kemuluran kulit sangat tergantung pada tahapan-tahapan proses sebelum finishing, yaitu tahap penyamakan dan fatliquoring, yang berada di luar ruang lingkup penelitian ini. Namun demikian, dalam artikel ini juga ditampilkan data hasil uji parameter-parameter tersebut di atas sebagai gambaran pengaruh proses embossing terhadap ketiga parameter tersebut.

Nilai rata-rata hasil uji ketahanan sobek, kemuluran, dan kekuatan tarik pada berbagai jumlah binder uretan dan motif embossing, masing-masing dapat dilihat pada Gambar 5, 6, dan 7.

Secara umum, Gambar 5, 6, dan 7 menunjukkan bahwa nilai ketahanan sobek, kemuluran, dan kekuatan tarik cenderung mengalami penurunan

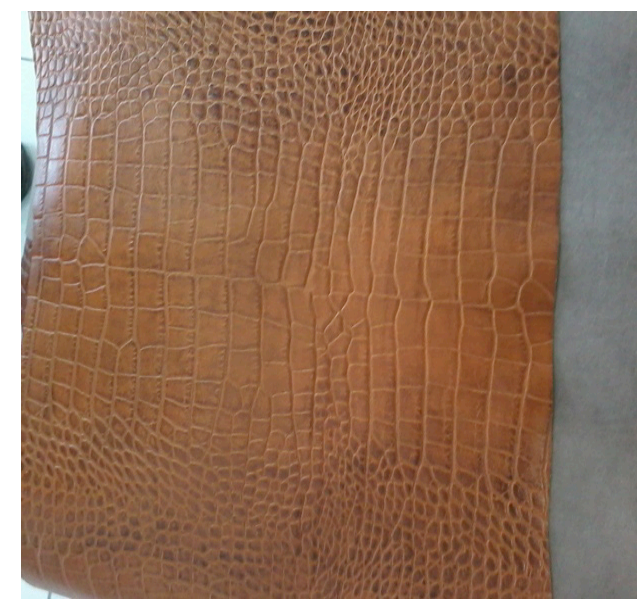

Gambar 4. Perbandingan kenampakan kulit tanpa motif(kiri) dengan kulit yang melalui proses embossing dengan motif buaya (kanan). 
untuk kulit tanpa dan dengan berbagai motif, dibandingkan dengan kulit tanpa perlakuan (kulit kras tanpa proses finishing), meskipun tampak beberapa titik data dengan kecenderungan yang sebaliknya. Hal ini mengindikasikan adanya pengaruh proses plating dan embossing yang menggunakan suhu dan tekanan tinggi terhadap struktur serat kulit. Suhu yang tinggi dapat menyebabkan terputusnya ikatan silang antar serat kolagen sehingga kekuatan tarik menurun. Selain itu, tekanan yang tinggi dapat menyebabkan keluarnya molekul-molekul minyak dari sela-sela serat kolagen dan membuat susunan serat menjadi lebih padat, sehingga kekuatan sobek dan kemuluran kulit juga menurun.

Beberapa titik data yang menunjukkan kecenderungan yang sebaliknya mungkin disebabkan adanya ketidakseragaman sampel kulit dan proses sebelum finishing.

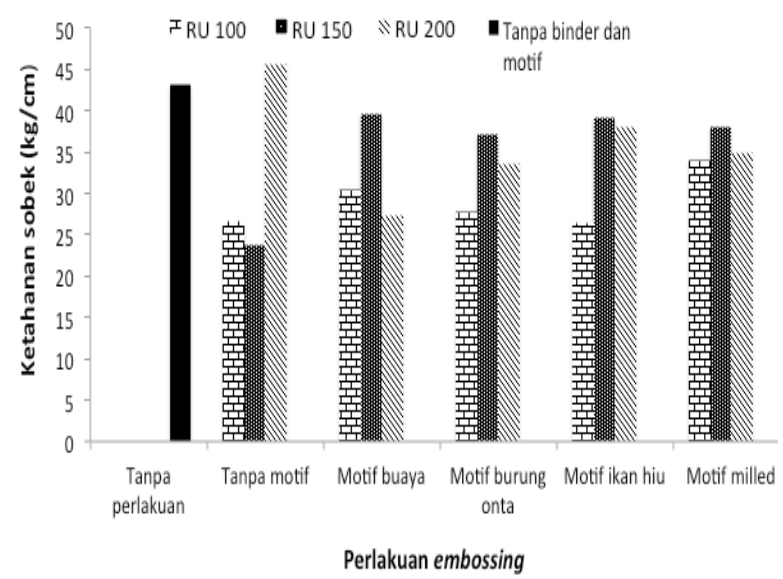

Gambar 5. Hasil uji ketahanan sobek pada berbagai jumlah binder uretan dan berbagai motif embossing

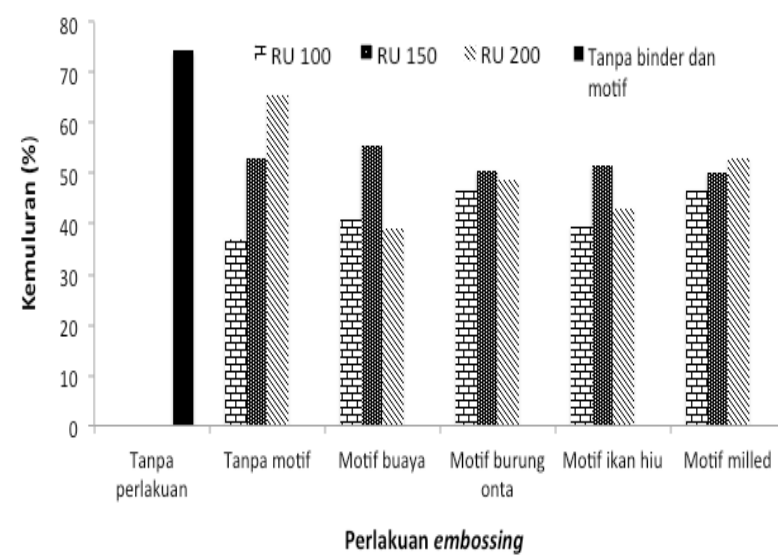

Gambar 6. Hasil uji kemuluran pada berbagai jumlah binder uretan dan berbagai motif embossing.

\section{Ketahanan Bengkuk}

Hasil uji ketahanan bengkuk 20.000 kali kulit sapi untuk semua perlakuan, baik yang tanpa maupun dengan berbagai motif adalah nerf dan cat tidak retak. Hal ini menunjukkan bahwa semua variasi komposisi bahan finishing yang digunakan dalam penelitian ini menghasilkan lapisan film yang compatible dengan permukaan kulit. Selain itu, suhu plating dan embossing sudah optimal, sehingga lapisan film yang dihasilkan merekat kuat dan tahan terhadap perlakuan bengkuk 20.000 kali. Hal ini juga berarti bahwa motif kulit buaya, burung unta, ikan hiu, dan milled tidak mempengaruhi ketahanan bengkuk kulit.

\section{Ketahanan Gosok Cat Tutup}

Hasil uji ketahanan gosok cat tutup (kering, basah) dalam penelitian ini dapat dilihat pada Tabel 4. Rata-rata hasil uji ketahanan gosok cat kering maupun basah adalah tidak luntur dengan nilai 5 (kering) dan nilai 4/5 (basah). Data ini menunjukkan bahwa formula lapisan atas menggunakan bahan nitroselulosa dapat melindungi lapisan di bawahnya sehingga tahan terhadap gosokan (tidak luntur) baik terhadap gosokan secara kering maupun basah. Hal ini sesuai dengan referensi Gumel \& Dambatta (2013) dan Wakaso (2014) yang menyatakan bahwa lapisan atas menggunakan nitroselulosa dapat memberikan perlindungan pada permukaan kulit, tahan terhadap air dan gosokan.

\section{Kekuatan rekat cat tutup (kering dan basah)}

Rata-rata hasil uji kekuatan rekat cat tutup kering dan basah dalam penelitian ini disajikan masing-masing pada Gambar 8 dan 9.

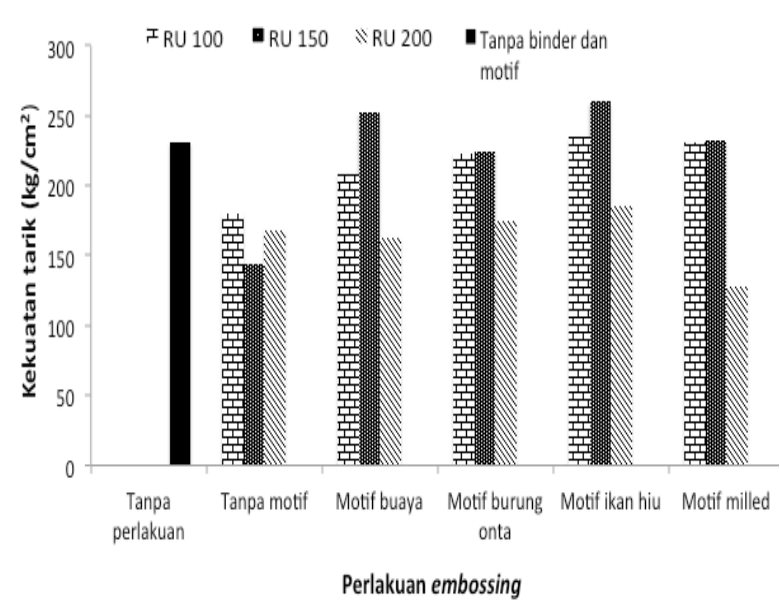

Gambar 7. Hasil uji kekuatan tarik pada berbagai jumlah binder uretan dan berbagai motif embossing. 
Tabel 4. Rata-rata hasil uji ketahanan gosok cat tutup (kering, basah)

\begin{tabular}{ccc}
\hline Perlakuan embossing/motif & Kering & Basah \\
\hline Tanpa embossing/motif & & \\
RU100 & 5 & 5 \\
RU150 & 5 & 5 \\
RU 200 & 5 & 5 \\
Motif kulit buaya & & \\
RU 100 & 5 & $4 / 5$ \\
RU 150 & 5 & $4 / 5$ \\
RU 200 & 5 & $4 / 5$ \\
Motif kulit burung unta & & \\
RU 100 & 5 & 5 \\
RU 150 & 5 & $4 / 5$ \\
RU 200 & 5 & $4 / 5$ \\
Motif kulit ikan hiu & & \\
RU 100 & 5 & $4 / 5$ \\
RU 150 & 5 & $4 / 5$ \\
RU 200 & 5 & $4 / 5$ \\
Motif milled & & \\
RU 100 & 5 & $4 / 5$ \\
RU 150 & 5 & $4 / 5$ \\
RU 200 & 5 & $4 / 5$ \\
\hline
\end{tabular}

Binder/ resin uretan merupakan perekat yang baik jika mengalami curing dengan baik (pada suhu dan tekanan yang tepat). Pada Gambar 8 tampak bahwa secara umum bertambahnya jumlah resin uretan meningkatkan nilai kekuatan rekat cat tutup dalam kondisi kering, yaitu pada motif kulit burung unta, ikan hiu, dan milled. Hal ini mengindikasikan bahwa kondisi operasi proses embossing sudah tepat dan menghasilkan perekat (binder) yang kuat merekat pada substrat kulit. Kecenderungan yang terbalik pada motif buaya dapat merupakan outlier. Sebagai tambahan, SNI 0234: 2009 mensyaratkan nilai minimum $200 \mathrm{~g} /$ $\mathrm{cm}$ untuk kekuatan rekat cat tutup (kering) kulit bagian atas alas kaki - kulit boks. Dalam hal ini, semua perlakuan dalam penelitian ini menghasilkan kekuatan rekat cat tutup (kering) yang telah melebihi nilai minimum yang disyaratkan.

Berbeda dengan saat kondisi kering, kondisi basah dapat menyebabkan menurunnya kekuatan rekat binder pada substrat, karena molekulmolekul air dapat menghalangi adhesi antara binder dengan substrat, demikian juga kohesi antara bahan-bahan dalam binder itu sendiri.

Gambar 9 menunjukkan bahwa secara umum RU 150 merupakan komposisi yang optimal dari binder, dimana pada komposisi tersebut, kekuatan

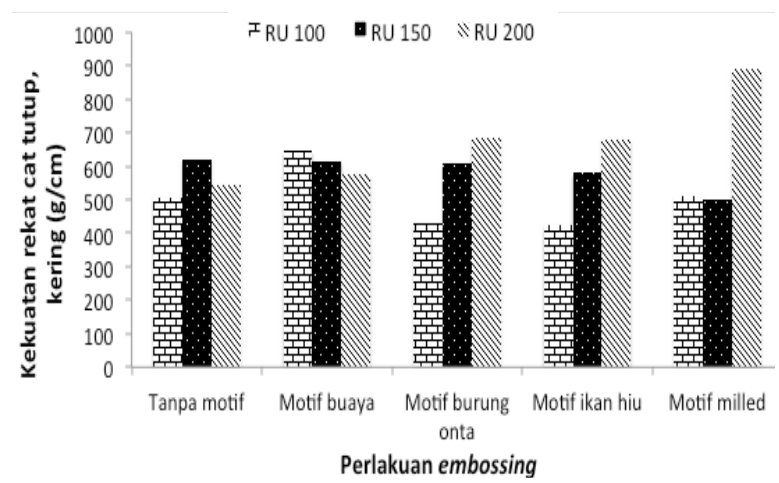

Gambar 8. Hasil uji kekuatan rekat cat tutup, kering.

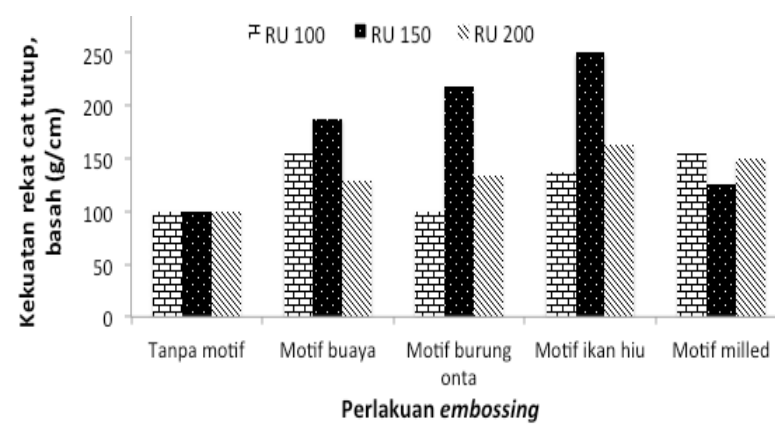

Gambar 9. Hasil uji kekuatan rekat cat tutup, basah.

rekat cat tutup (basah) menunjukkan nilai paling tinggi dibandingkan dengan komposisi RU 100 dan RU 200. Hal ini terutama tampak pada kulit dengan motif kulit buaya, burung unta, dan ikan hiu. Namun jika ditinjau dari persyaratan SNI 0234: 2009 Kulit bagian atas alas kaki - kulit boks di mana kekuatan rekat cat tutup (basah) minimal adalah $100 \mathrm{~g} / \mathrm{cm}$, semua perlakuan dalam penelitian ini telah memenuhi persyaratan tersebut.

Hasil uji kekuatan rekat cat tutup yang tinggi (di atas nilai minimum), baik secara kering maupun basah menunjukkan bahwa formulasi finishing, terutama komposisi antara resin akrilik (RA) dan resin poliuretan (RU) sudah optimum. Selain itu, terdapat kecocokan antara lak dan binder yang digunakan pada lapisan dasar (base coat), sehingga ikatan kohesi dan adhesi menjadi kuat dan lapisan film yang terbentuk dapat merekat kuat pada permukaan kulit.

\section{Sifat Fisis}

Water vapor permeability (WVP) dan water vapor absorption (WVA)

Hasil uji WVP dan WVA dalam penelitian ini masing-masing disajikan pada Gambar 10 dan 11. Menurut penelitian yang dilakukan (Smiechows- 
ki et al., 2014), nilai WVP kulit kras lebih tinggi daripada kulit finish, hal ini terbukti dan dapat dilihat pada Gambar 10, WVP kulit kras lebih tinggi dari WVP kulit sapi yang telah di finish baik tanpa motif maupun dengan motif. Penurunan WVP disebabkan adanya pengaruh perlakuan panas sehingga terjadi pengurangan jumlah gugus hidrofilik dari makromolekul kolagen yang menurunkan porositas kulit (Smiechowski et al., 2014). Ditinjau dari penambahan binder RU, pada Gambar 10 nampak bahwa nilai WVP cenderung meningkat dari penggunaan binder RU 150 dan 200 bagian, baik kulit tanpa motif maupun dengan diberi motif (buaya, burung unta, ikan hiu, milled). Nilai WVP tertinggi dicapai oleh pemakaian jumlah binder RU 200 bagian, baik untuk kulit tanpa emboss maupun dengan emboss/ diberi motif (buaya, burung unta, ikan hiu, milled). Hal ini sesuai de-

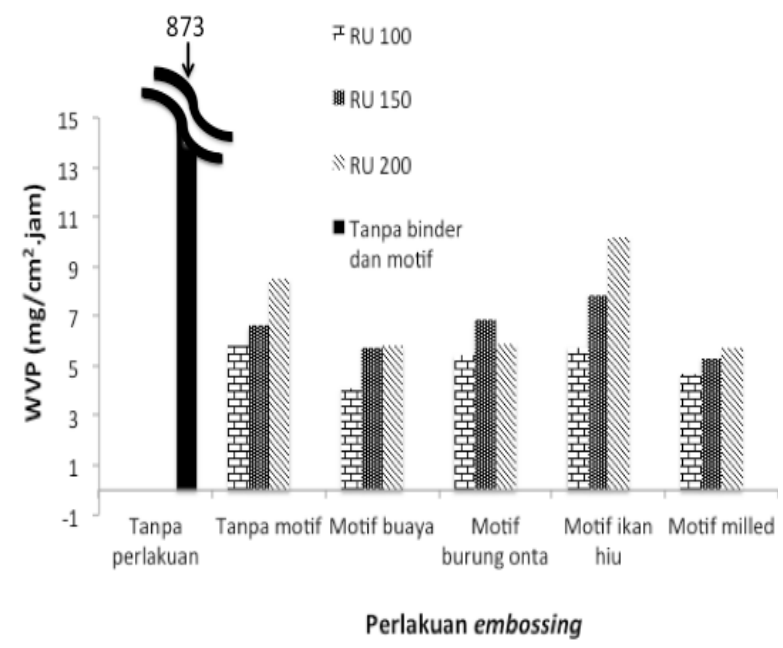

Gambar 10. Hasil uji WVP pada kulit tanpa perlakuan (kras) dan dengan perlakuan plating dan embossing.

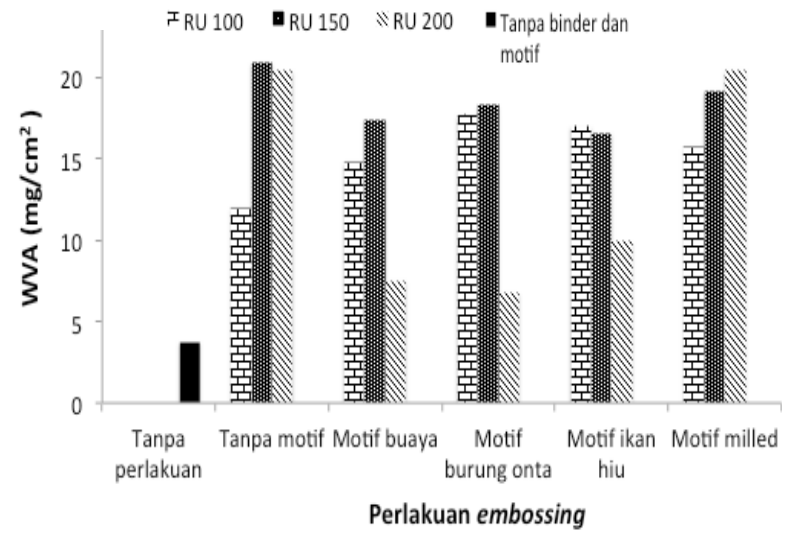

Gambar 11. Hasil uji WVA pada kulit tanpa perlakuan (kras) dan dengan perlakuan plating dan embossing. ngan pernyataan Jankauskaite et al. (2014) bahwa binder uretan mempunyai sifat WVP yang baik. Melihat pernyataan tersebut maka perlakuan yang optimal terkait dengan nilai WVP adalah dengan penggunaan binder RU 200 bagian. Bila ditinjau dari berbagai jenis motif yang diaplikasikan maka nilai WVP yang optimal adalah dengan aplikasi motif ikan hiu dengan nilai WVP $10,18 \mathrm{mg} / \mathrm{cm}^{2}$. jam. Semua perlakuan memenuhi persyaratan ISO/TR 20879: 2007, footwear performance requirements for footwear-upper (ISO, 2007a) yang mempersyaratkan WVP $\geq 0,8 \mathrm{mg} / \mathrm{cm}^{2}$.jam.

Rata-rata hasil uji water vapour absorption (WVA) kulit sapi disajikan pada Gambar 11. Pada Gambar 11 nampak bahwa nilai WVA ada kecenderungan meningkat dari penggunaan binder RU 100, 150, dan 200 bagian baik untuk kulit tanpa motif maupun dengan diberi motif (buaya, burung unta, ikan hiu, milled). Semua perlakuan memenuhi persyaratan ISO/TR 20879: 2007, footwear performance requirements for footwearupper (ISO, 2007a) yang mempersyaratkan WVA $\geq 8 \mathrm{mg} / \mathrm{cm}^{2}$.

Pada Gambar 11 menunjukkan bahwa pelapisan sampel kulit dengan binder uretan menyebabkan meningkatnya nilai WVA. Menurut Jankauskaite et al. (2014) bahwa pelapisan kulit split dengan lapisan adesif non-permeable meningkatkan nilai WVA hampir dua kali dibandingkan dengan kulit tanpa lapisan. Jankauskaite selanjutnya mengasumsi bahwa kenaikan WVA tersebut terjadi karena kondensasi dan akumulasi uap air di area dekat lapisan adesif yang permeabilitasnya rendah. Dalam penelitian ini, kenaikan WVA dapat disebabkan adanya interaksi yang kuat antara molekul air dengan kolagen, yang diikuti dengan kondensasi dan akumulasi uap air seperti telah disebutkan di atas, di area sekitar lapisan polimer dengan permeabilitas rendah yang menutup poripori kulit.

\section{Scanning Electron Microscopy (SEM)}

Perubahan morfologi kulit sebelum perlakuan (kulit kras) dan setelah perlakuan finishing diobservasi menggunakan SEM. Hasil SEM dari kulit kras (belum di finish) dan kulit finish polos (tanpa motif) dengan perbesaran $500 \mathrm{X}$, disajikan pada Gambar 12.

Pada Gambar 12(a) tampak bahwa struktur jaringan lebih porous dibanding Gambar 12 (b), karena pori-pori kulit kras masih natural dan tidak ada perlakuan baik pelapisan maupun pemanasan 
(plating). Gambar 12 (b), 13 (a)-(d) tampak adanya tambahan lapisan tipis film pada kulit finish karena kulit telah mengalami perlakuan pelapisan (coating) dan pemanasan dan tekanan baik perlakuan plating dan atau embossing, sehingga tampak adanya perubahan struktur jaringan serat kulit di mana kulit kras tampak berpori dengan jarak antar serat relatif lebih berjauhan.

Gambar 13 (a)-(d) masing-masing menunjukkan hasil SEM untuk penampang melintang kulit finish dengan motif kulit buaya, burung unta, ikan hiu dan milled (dikenai proses embossing
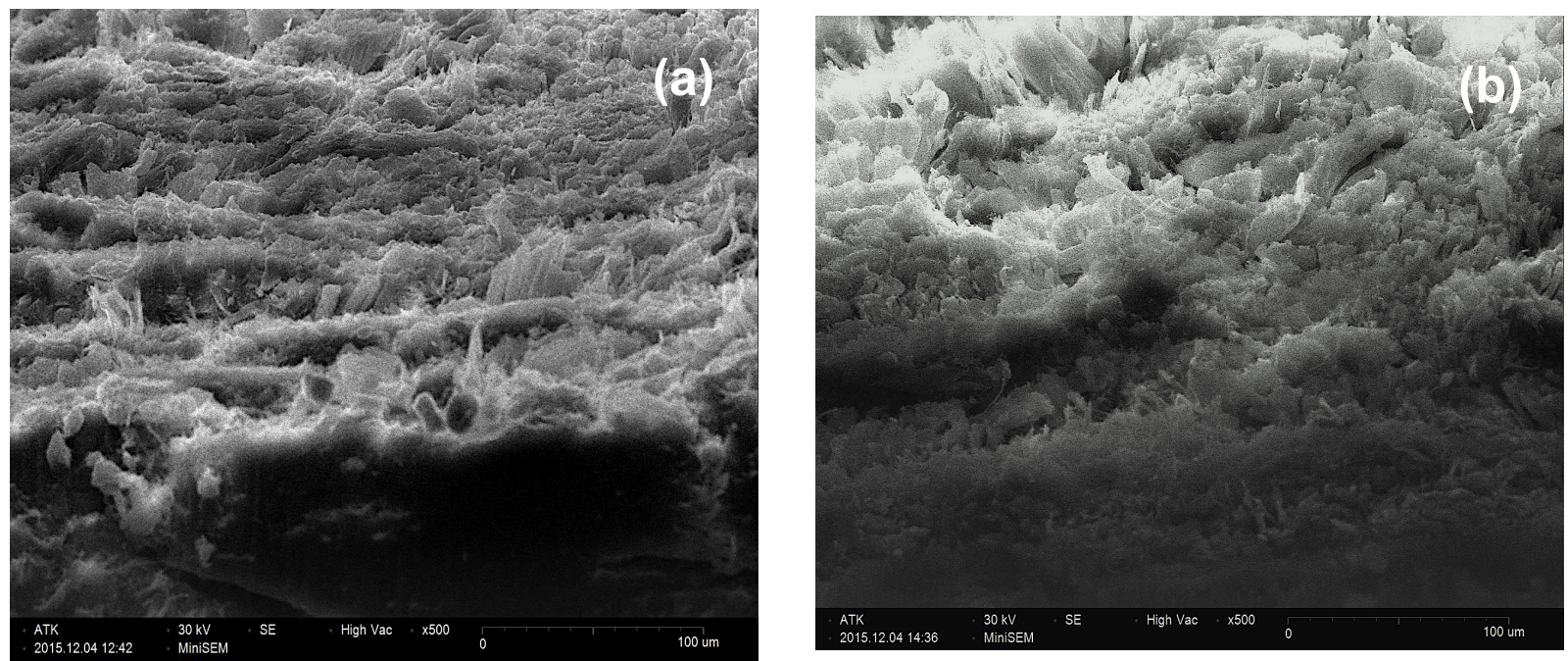

Gambar 12. Penampang melintang (a) kulit kras dan (b) kulit finish polos, perbesaran 500X.
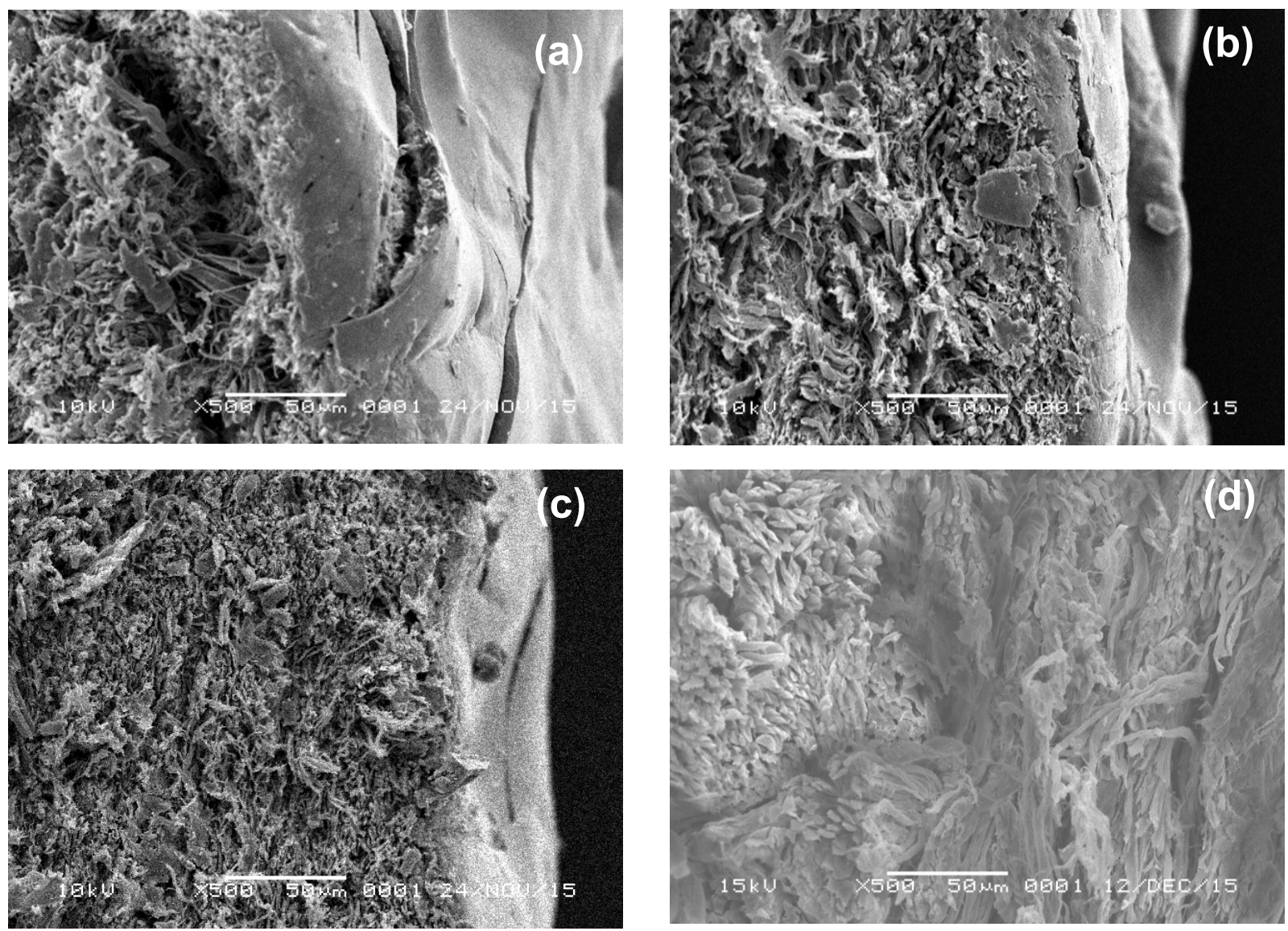

Gambar 13. Penampang melintang kulit finish dengan berbagai motif (a) kulit buaya, (b) kulit burung unta, (c) ikan hiu dan (d) milled, perbesaran 500X. 
dan plating). Dari berbagai motif yang diaplikasikan, menunjukkan bahwa motif ikan hiu (Gambar 13(c)) nampak lebih padat dan kompak dibandingkan motif lainnya. Hal ini disebabkan karena bentuk motif ikan hiu luasan areanya lebih sempit dibandingkan dengan luas area motif lainnya, sehingga dengan perlakuan tekanan yang tinggi akan lebih mampat, apalagi perlakuan emboss dilakukan 2 (dua) kali yaitu dengan arah melintang dan membujur.

\section{KESIMPULAN}

Data hasil penelitian menunjukkan bahwa penambahan binder uretan (RU) dan pemberian motif pada kulit reject meningkatkan kualitas kulit terutama dari segi kenampakan. Secara visual, kulit yang paling disukai panelis adalah kulit dengan penambahan binder RU sebesar 200 bagian dan bermotif kulit buaya.

Sifat-sifat mekanik pada penambahan binder RU 200 bagian, dengan nilai ketahanan bengkuk 20.000 kali bengkukan: nerf dan cat tidak retak; ketahanan gosok cat tutup 5 (kering) dan 4/5 (basah); kuat rekat cat tutup $575 \mathrm{~g} / \mathrm{cm}$ (kering) dan $129,17 \mathrm{~g} / \mathrm{cm}$ (basah) semuanya menunjukkan nilai parameter di atas persyaratan minimum untuk kulit sepatu bagian atas; kekuatan tarik 162,66 kg/ $\mathrm{cm}^{2}$; kemuluran 38,94\%; ketahanan sobek 27,45 $\mathrm{kg} / \mathrm{cm}$; WVP 5,83 mg/cm².jam dan WVA 7,2 mg/ $\mathrm{cm}^{2}$.

Hasil pengamatan morfologi dari kulit kras (unfinish) dibandingkan dengan kulit finish tanpa dan dengan motif tampak lebih berpori dengan jarak antar serat relatif lebih berjauhan. Sedang kulit finish tanpa dan dengan motif tampak adanya lapisan film yang tipis dan perubahan struktur jaringan serat. Penambahan binder RU dan pemberian motif dengan metode embossing cenderung memberikan pengaruh yang positif terhadap kualitas kulit reject, sehingga dapat dipertimbangkan sebagai salah satu alternatif solusi dalam rangka meningkatkan nilai jual kulit reject.

\section{UCAPAN TERIMA KASIH}

Ucapan terima kasih kami sampaikan kepada Thomas Tukirin, Wahono, Mursulasno, Sarjo dan Heri Kustanto yang telah membantu dalam kegiatan penelitian ini.

\section{DAFTAR PUSTAKA}

Basaran, B., Yorgancioglu, A., \& Onem, E. (2012). A novel approach in leather finishing: surface modification with flock fibers. Textile Research Journal, 82(15), 1509-1516, http://dx.doi.org/10.1177/0040517512449048

Bekele M. (2014). Approach towards high performance WVP upper leather from goat skin (Thesis). Addis Ababa University, Ethiopia.

BSN (Badan Standardisasi Nasiional). (1994). Standard Nasional Indonesia SNI 06-3534:1994 Kulit sapi pikel untuk ekspor. Jakarta, Indonesia: BSN.

Fountura, J. T., \& Gutterres, M. (2015). Damage of pickled hides, wet blue leather and vegetable tanned leather due to biodeterioration. Journal of the American Leather Chemist Association, 110(5), 138-144.

Gulbiniene, A., Jankauskaite, V., Saceviciene, V., \& Mickus, K. (2007). Investigation of water vapour resorption/desorption of textile laminates. Material Science Medziagotyra, 13(3), 255-261.

Gumel, S. M., \& Dambatta, B. B. (2013). Application and evaluation of the performance of poly(vinyl alcohol) and its blend with nitrocelulose in leather top coating. International Journal of Chemical Engineering and Applications, 4(4), 249-253, http://dx.doi.org/10.7763/IJCEA.2013.V4.305

Hoefler, J., Hageman, B., Chung, C. J., \& Smith, R. (2013). High performance acrylic polymer technology for use in the leather finishing process. Journal of American Leather Chemists Association, 108(8), 311-317.

ISO (International Standard Organization). (2007). ISO 20879:2007 Footwear performance requirements for footwear-upper. Jenewa, Swiss: International Standard Organization.

ISO (International Standard Organization). (1998). ISO 2822-1:1998 Raw cattle hides and calf skins - Part 1: Descriptions of defects. Jenewa, Swiss: International Standard Organization.

Jankauskaite, V., Gulbiniene , A., Jiyembetova, I., Sirvaityte, J., Urbelis, V., \& Mickus, K. V. (2014). Comparable evaluation of leather waterproofing behaviour upon hide quality. II. Influence of finishing on leather properties. Materials Science, 20(2), 165-169, http://dx.doi.org/10.5755/j01.ms.20.2.2339

Kabeer, S. S . (2014). Water based finishes for leather products. India: STAHL.

Niculescu, O., Leca, M., Moldovan, Z., Chelaru, C., Gurau, D., \& Berechet, D. M. (2015). Obtaining and characterization of an ecologic wax emulsions for finishing natural leathers and furs. Revistadechimie (Bucharest), 66, 1173-1176.

Smiechowski K., Zarlok, J., \& Kowalska, M. (2014). The relationship between water vapour permeability and softness for leathers produced in poland. Journal of the Society of Leather Technologist \& Chemist, 98(6), 259-263.

Tang, K., Wang, F., Liu J., Jia, P., \& Liu, J. (2013). 
Water vapour permeability of leathers by grey system theory. Advanced Material Science, 33, 373-382.

Wakaso, M. (2014). Studies on effect of different pigment and binder combination on surface property of finished leather (Thesis). Addis Ababa University, Ethiopia

Wang, X.C., Lu, X.B., Qiang, T., \& Ren, L. (2010). Preparation and application properties analysis of hyperbranched polyurethane leather finishing agent. Advanced Materials Research, 129, 251255, http://dx.doi.org/10.4028/www.scientific. net/amr.129-131.251
Widari, W., Nurhafic, M., \& Tukirin, T. (2007). Pembuatan kulit motif reptil dari kulit sapi kualitas rendah untuk atasan sepatu. Yogyakarta, Indonesia: Balai Besar Kulit, Karet, dan Plastik. 